Open Access

Research Article
Res. Agric. Livest. Fish.

Vol. 2, No. 2, August 2015: 369-374

\title{
COMPARATIVE STUDY ON GROWTH PERFORMANCE OF THAI SHARPUNTI (Puntius gonionotus) USING TWO DIFFERENT WEEDS DUCK WEED (Lemna minor) AND AZOLLA FERN (Azolla pinneta)
}

\section{Gias Uddin Ahmed, Md. Mamunur Rahman*, Mohammad Nurul Alam and Baadruzzoha Sarker ${ }^{1}$}

Department of Aquaculture, Faculty of Fisheries, Bangladesh Agricultural University Mymensingh-2202, Bangladesh; ${ }^{1}$ Production Officer, BRAC Fish Hatchery Srimangal, Moulvibazar-3210, Bangladesh

*Corresponding author: Md. Mamunur Rahman, E-mail- mamunurrahman125@gmail.com

\begin{tabular}{|c|c|}
\hline ARTICLE INFO & ABSTRACT \\
\hline $\begin{array}{l}\text { Accepted } \\
17.08 .2015 \\
\text { Online } \\
04.09 .2015 \\
\text { Key words } \\
\text { Thai Sharpunti } \\
\text { Duck weed } \\
\text { Azolla fern } \\
\text { Growth } \\
\text { performances }\end{array}$ & 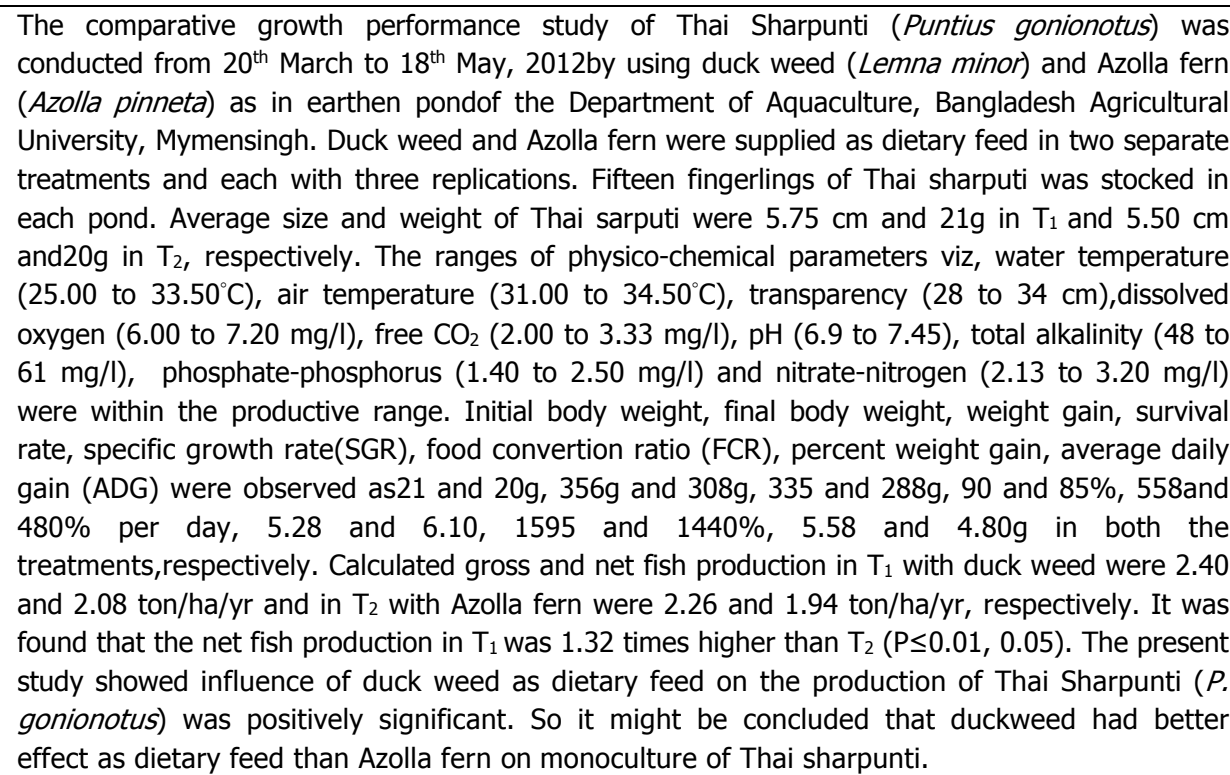 \\
\hline
\end{tabular}

To cite this article: GU Ahmed, MM Rahman, MN Alam and B Sarker, 2015. Comparative study on growth performance of thai sharpunti (Puntius gonionotus) using two different weeds duck weed (Lemna minor) and azolla fern (Azolla pinneta). Res. Agric. Livest. Fish. 2 (2): 369-374.

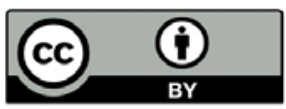

This is an open access article licensed under the terms of the Creative Commons Attribution 4.0 International License

www.agroaid-bd.org/ralf, E-mail: editor.ralf@gmail.com 


\section{INTRODUCTION}

Fisheries sector has been playing a significant role in nutrition, employment, foreign exchange earnings, food supply and more importantly socioeconomic stability in the rural areas. In 2009-2010 total fish production of Bangladesh was 28.99 lakh metric tons but that is not enough for our growing population. Therefore, immediate attention must be given to maximize the fish production by minimizing the production cost for everincreasing population as well as to build up the national economy. In Bangladesh more or less every rural homestead has a back yard pond which retains water for about 9-12 months. There are 2.86 million ponds in Bangladesh covering an area of 28,834 ha (Rahman and Hussain, 2000). The average fish production in traditionally managed ponds in Bangladesh was estimated to be $870.0 \mathrm{~kg} / \mathrm{ha} / \mathrm{year}$ which is very low and that can be increased by many fold through improved culture and management practices. Considering the aquaculture potential of Puntius gonionotus, it was introduced to Bangladesh from Thailand in 1977. It grows fast, reaches marketable size within four months and is ideal for seasonal pond and road side ditches. In perennial water bodies, polyculture or mono culture of this sharpunti has economically viable and technically sustainable. Silver barb feeds on macrophytes including duck weed (Lemna spp.) and Azolla fern (Azolla spp.) and sharpunti is an appropriate species for culturing seasonal ponds and rice fields in monoculture. Noor et al. (2000) evaluated the suitability of duckweed as dietary fish meal substitute for silver barb and found that $10 \%$ of the dietary fish meal protein could be replaced by duckweed in the diet. Azim and Wahab (2003) found that duckweed has significant positive effect on growth rates of exotic Thai silver barb, common carp and indigenous catla fish. Silver barb respond well to comparatively low cost simple management practices (Akhtaruzzaman, 1991). Duck weed and Azolla holds a great potential as a cheap source of fish food. Many works already done on duck weed used as fish, but there is no work have so far been under taken about the comparative growth performance of Thai sharpunti feeding on duck weed and water fern. The present studies on the ingestion rate and growth performance of Puntius gonionotus were under taken to evaluate the conversion efficiency of duck weed and Azolla fern by Thai sharpunti and to study the comparative proximate composition energy distribution of duck weed and Azolla fern.

\section{MATERIALS AND METHODS}

A series of six ponds of Department of Aquaculture, Bangladesh Agricultural University, Mymensingh, were selected to conduct the research work from $20^{\text {th }}$ March to $18^{\text {th }}$ May, 2012. The ponds are rectangular in shape. The size, depth, basin conformation of all the six ponds are more or less similar. The ponds are free from aquatic vegetation and well-exposed to sunlight. The surface area of each of the ponds is about $26 \mathrm{~m}^{2}$ with an average water depth of 1.0meter. The ponds were completely dependent on water supply from a deep tube-well. The pond's wall is well protected and covered with fine net. Fifteen fingerlings of Thai sharpunti $(P$. gonionotus) were stocked in each the pond. The average length and weight of sharpunti were $5.50 \mathrm{~cm}$, and 21 g. After collection the fresh weeds were weighed and then supplied to the fish culture ponds under treatment1 and treatment- 2 at the rate of $60 \%$ of total body weight of all the fish of the ponds. The physical parameters such as temperature $\left({ }^{\circ} \mathrm{C}\right)$ and transparency $(\mathrm{cm})$ and chemical water quality parameters such as dissolved oxygen $(\mathrm{mg} / \mathrm{l}), \mathrm{pH}$, free carbondioxide $(\mathrm{mg} / \mathrm{l})$, total alkalinity $(\mathrm{mg} / \mathrm{l})$, phosphate phosphorus $\left(\mathrm{PO}_{4}-\mathrm{P}\right)(\mathrm{mg} / \mathrm{l})$, nitrate nitrogen $\left(\mathrm{NO}_{3}-\mathrm{N}\right)(\mathrm{mg} / \mathrm{l})$ were done by water quality parameters test kits.

\section{Estimation of growth performances of Sharpunti (Puntius gonionotus)}

(a) Mean weight gain $(\mathrm{g})=$ Final weight- Initial weight

(b) Percent weight gain $(\%)=\frac{\text { Final weight-Initial weight }}{\text { Initial weight }} \times 100$

(c) Average daily gain $(\mathrm{g})=\frac{\text { Final weight-Initial weight }}{60}$

(d) The survival rate was estimated by the following formula:

Survival rate $(\%)=\frac{\text { No. of stocked fishes }}{\text { No.of harvested fishes }} \times 100$ 
(e) Specific growth rate (SGR \% per day) was estimated by the following formula:

$\operatorname{SGR}(\%$ per day $)=\frac{\log _{\mathrm{e}} W_{2}-\log _{\mathrm{e}} W_{1}}{T_{2}-T_{1}} \times 100$

Where, $W_{1}=$ Initial live body weight $(g)$ at time $T 1$ (day).

$\mathrm{W}_{2}=$ Final live body weight $(\mathrm{g})$ at time $\mathrm{T} 2$ (day).

(f) Food conversion ratio $(F C R)=\frac{\text { Feed fed (dry matter })}{\text { Live weight gain }}$

(g) Calculated gross production (ton/ha/yr) $=\frac{\text { Final weight }(\mathrm{g}) \times 10000 \times 365}{60 \times 1000 \times 1000 \times 9}$

(h) Calculated net production (ton/ha/yr) $=\frac{\text { Mean weight }(\mathrm{g}) \times 10000 \times 365}{60 \times 1000 \times 1000 \times 9}$

(i) Analysis of proximate composition of duckweed and Azolla fern.

(j) Energy distributionof Thai Sharpunti (Puntius gonionotus).

\section{Statistical analysis}

F-test of growth performance of Thai Sharpunti ( $P$. gonionotus) in treatment-1 and treatment -2 was done by a computer using SPSS package programme.

\section{RESULTS AND DISCUSSION}

\section{Physical and chemical parameters}

The results of the physical and chemical parameters recorded during the experimental period presented in the Table 1 and Table 2.

Table 1. Fluctuations of physical parameters in treatment-1 and treatment-2 during the experimental period

\begin{tabular}{|c|c|c|c|c|c|c|c|c|c|c|}
\hline \multirow[t]{2}{*}{ Parameter } & \multirow{2}{*}{ Treatment } & \multicolumn{8}{|c|}{ Sampling date } & \multirow{2}{*}{$\begin{array}{l}\text { Meant } \\
\text { S.D }\end{array}$} \\
\hline & & $20 \mathrm{Mar}$ & $\begin{array}{l}28 \\
\text { Mar }\end{array}$ & $\begin{array}{l}6 \\
\text { Apr }\end{array}$ & $\begin{array}{l}15 \\
\text { Apr }\end{array}$ & $\begin{array}{l}23 \\
\text { Apr }\end{array}$ & $\begin{array}{l}2 \\
\text { May }\end{array}$ & $\begin{array}{l}10 \\
\text { May }\end{array}$ & $\begin{array}{l}18 \\
\text { May }\end{array}$ & \\
\hline \multirow[t]{2}{*}{$\begin{array}{l}\text { Transparency } \\
(\mathrm{cm})\end{array}$} & $\mathbf{T}_{1}$ & 32.33 & 30.00 & 29.00 & 28.00 & 31.00 & 30.33 & 32.33 & 30.33 & $30.41 \pm 2.04$ \\
\hline & $\mathrm{T}_{2}$ & 34.00 & 33.33 & 29.33 & 31.33 & 32.33 & 34.00 & 34.33 & 32.00 & $32.58 \pm 1.48$ \\
\hline \multirow{2}{*}{$\begin{array}{l}\text { Water } \\
\text { temperature } \\
\left({ }^{\circ} \mathrm{C}\right)\end{array}$} & $\mathbf{T}_{1}$ & 29.25 & 30.25 & 32.00 & 31.50 & 32.75 & 32.75 & 32.25 & 31.00 & $31.46 \pm 1.37$ \\
\hline & $\mathbf{T}_{2}$ & 30.50 & 33.33 & 32.33 & 32.50 & 33.33 & 33.50 & 33.00 & 31.33 & $32.47 \pm 1.14$ \\
\hline \multirow{2}{*}{$\begin{array}{l}\text { Air } \\
\text { temperature } \\
\left({ }^{\circ} \mathrm{C}\right)\end{array}$} & $\mathbf{T}_{1}$ & 31.50 & 32.00 & 32.80 & 33.00 & 34.00 & 34.50 & 33.00 & 32.40 & $32.97 \pm 1.04$ \\
\hline & $\mathbf{T}_{2}$ & 31.50 & 32.00 & 32.80 & 33.00 & 34.00 & 34.50 & 33.00 & 33.50 & $33.03 \pm 1.04$ \\
\hline
\end{tabular}


Table 2. Fluctuations of chemical parameters in treatment-1 and treatment-2 during the experimental period

\begin{tabular}{|c|c|c|c|c|c|c|c|c|c|c|}
\hline \multirow[b]{2}{*}{ Parameter } & \multirow[b]{2}{*}{ Treatment } & \multicolumn{8}{|c|}{ Sampling date } & \multirow[b]{2}{*}{ Mean \pm S.D } \\
\hline & & $\begin{array}{c}20 \\
\text { Mar }\end{array}$ & $\begin{array}{c}28 \\
\text { Mar }\end{array}$ & $\begin{array}{c}6 \\
\text { Apr }\end{array}$ & $\begin{array}{c}15 \\
\text { Apr }\end{array}$ & $\begin{array}{c}23 \\
\text { Apr }\end{array}$ & $\begin{array}{c}2 \\
\text { May }\end{array}$ & $\begin{array}{c}10 \\
\text { May }\end{array}$ & $\begin{array}{c}18 \\
\text { May }\end{array}$ & \\
\hline \multirow{2}{*}{$\begin{array}{l}\text { Dissolved } \\
\text { Oxygen } \\
\text { (mg/L) }\end{array}$} & $\mathrm{T}_{1}$ & 6.90 & 7.10 & 6.70 & 6.80 & 6.63 & 6.60 & 6.10 & 6.46 & $6.66 \pm 0.34$ \\
\hline & $\mathbf{T}_{2}$ & 6.83 & 7.20 & 6.33 & 6.90 & 6.40 & 6.33 & 5.90 & 6.43 & $6.54 \pm 0.45$ \\
\hline \multirow{2}{*}{$\begin{array}{l}\mathrm{FreeCO}_{2} \\
(\mathrm{mg} / \mathrm{L})\end{array}$} & $\mathbf{T}_{1}$ & 3.23 & 2.93 & 3.13 & 3.00 & 2.30 & 2.70 & 2.60 & 2.60 & $2.81 \pm 0.35$ \\
\hline & $T_{2}$ & 3.33 & 3.00 & 3.00 & 3.20 & 2.93 & 2.85 & 2.33 & 2.80 & $2.93 \pm 0.28$ \\
\hline \multirow{2}{*}{ pH } & $\mathrm{T}_{1}$ & 7.43 & 7.26 & 6.93 & 7.13 & 6.90 & 7.20 & 7.13 & 7.00 & $7.12 \pm 0.23$ \\
\hline & $T_{2}$ & 7.03 & 7.20 & 7.01 & 7.00 & 7.13 & 7.03 & 7.23 & 7.03 & $7.08 \pm 0.13$ \\
\hline \multirow{2}{*}{$\begin{array}{l}\text { Total } \\
\text { alkalinity } \\
(\mathrm{mg} / \mathrm{L})\end{array}$} & $\mathrm{T}_{1}$ & 50.33 & 48.00 & 53.00 & 49.33 & 52.33 & 50.33 & 51.33 & 50.00 & $50.58 \pm 1.98$ \\
\hline & $T_{2}$ & 47.33 & 48.33 & 53.00 & 48.00 & 61.33 & 53.33 & 50.33 & 49.66 & $50.16 \pm 2.67$ \\
\hline \multirow{2}{*}{$\begin{array}{l}\mathrm{PO}_{4}-\mathrm{P} \\
(\mathrm{mg} / \mathrm{L})\end{array}$} & $\mathrm{T}_{1}$ & 2.50 & 1.80 & 1.40 & 1.90 & 2.30 & 1.70 & 1.93 & 1.57 & $1.89 \pm 0.37$ \\
\hline & $T_{2}$ & 2.43 & 1.83 & 1.53 & 2.00 & 2.23 & 1.73 & 2.03 & 2.03 & $1.98 \pm 0.32$ \\
\hline \multirow{2}{*}{$\begin{array}{l}\mathrm{NO}_{3}-\mathrm{N} \\
(\mathrm{mg} / \mathrm{L})\end{array}$} & $\mathrm{T}_{1}$ & 2.90 & 2.13 & 2.63 & 2.90 & 3.20 & 2.40 & 3.00 & 2.86 & $2.75 \pm 0.39$ \\
\hline & $\mathbf{T}_{2}$ & 2.90 & 2.30 & 2.73 & 3.00 & 3.10 & 2.33 & 3.03 & 2.90 & $2.79 \pm 0.33$ \\
\hline
\end{tabular}

In the present study, range of water temperature was within suitable range for fish culture (29.25 to $33.50^{\circ} \mathrm{C}$ ). Wahab et al. (1994) found transparency ranging from $15-55 \mathrm{~cm}$ in polyculture pond. Kohinoor (2000) recorded transparency ranging from 15 to $58 \mathrm{~cm}$. In the present experiment, the transparency values in treatment-1 and treatment- 2 were closely near to productive range $(28$ to $34 \mathrm{~cm}$ ). Aminul (1996) stated that the water temperature ranged from 25 to $35^{\circ} \mathrm{C}$ was suitable for culture of fish.

Kohinoor (2000) measured dissolved oxygen 2 to $7.4 \mathrm{mg} / \mathrm{L}$ in the research ponds of Bangladesh Agricultural University campus, Mymensingh. From the above findings, it was concluded that the oxygen content of the present experimental ponds were within the good productive range. During the study period the fluctuations of free carbondioxide in treatment-1 and treatment-2 range from 2.30 to $3.33 \mathrm{mg} / \mathrm{L}$. The mean values of free carbondioxide were $2.81 \pm 0.35 \mathrm{mg} / \mathrm{L}$ in $\mathrm{T}_{1}$ and $2.93 \pm 0.28 \mathrm{mg} \mathrm{L}$ in $\mathrm{T}_{2}$. Israfil (2000) and Kabir (2003) observed more or less similar results. Fluctuations of the $\mathrm{pH}$ values of the experimental treatments ranged from 6.90 to 7.45 . The mean values of $\mathrm{pH}$ were $7.12 \pm 0.23$ in $\mathrm{T}_{1}$ and $7.08 \pm 0.13$ in $\mathrm{T}_{2}$. Dewan et al. (1991) stated that the optimum pH range for carp polyculture in pond is 6.5 to 9.0 .Israfil (2000) and Kabir (2003) found almost similar results. According to Rahman (1992) total alkalinity of productive ponds should be $20 \mathrm{ppm}$ or more. Total alkalinity in the experimental treatments ranged from 48.00 to $61.33 \mathrm{mg} / \mathrm{L}$. The mean values of total alkalinity were $50.58 \pm 1.98 \mathrm{mg} / \mathrm{L}$ in $\mathrm{T}_{1}$ and $50.16 \pm 2.67 \mathrm{mg} / \mathrm{L} \mathrm{T}$. The variations of phosphate-phosphorusranged from 1.40 to $2.50 \mathrm{mg} / \mathrm{L}$. The mean values of $\mathrm{PO}_{4}-\mathrm{P}$ were $1.89 \pm$ $0.37 \mathrm{mg} / \mathrm{L}$ in $\mathrm{T}_{1}$ and $1.98 \pm 0.32 \mathrm{mg} / \mathrm{L} \mathrm{T}_{2}$. Wahabet al. (1995) found the concentrations of phosphatephosphorus from0.09to5.20 mg/Lexperimental ponds at Bangladesh Agricultural University, Mymensingh. From the present findings, it might be concluded that phosphate-phosphorus content, were within the productive range.Variations of nitrate-nitrogen of ranged from 2.13 to $3.20 \mathrm{mg} / \mathrm{L}$ during the study period. The mean values of nitrate-nitrogen were $2.75 \pm 0.39 \mathrm{mg} / \mathrm{L}$ in $\mathrm{T}_{1}$ and $2.79 \pm 0.33 \mathrm{mg} / \mathrm{L}$ in $\mathrm{T}_{2}$. From the above discussion, it may be concluded that all the parameters of experimental ponds were suitable for fish culture.

\section{Growth Performances of Thai Sharpunti (Puntius gonionotus)}

The final weight was $356 \mathrm{~g}$ in $T_{1}$ and $308 \mathrm{~g}$ in $T_{2}$. The final weight in $T_{1}$ was significantly higher than $T_{2}(P$ $\leq 0.01$ ). The live weight gain was $335 \mathrm{~g}$ in $T_{1}$ and $288 \mathrm{~g}$ in $T_{2}$. The live weight gain in $T_{1}$ was significantly higher than $T_{2}(P \leq 0.01)$. The percent weight gain was $1595 \%$ in $T_{1}$ and $1440 \%$ in $T_{2}$. The percent weight gain in $T_{1}$ was significantly higher than $T_{2}(P \leq 0.05)$. The average daily weight gain was $5.58 \mathrm{~g}$ in $\mathrm{T}_{1}$ and $4.80 \mathrm{~g}$ in $\mathrm{T}_{2}$. The 
average daily weight gain in $T_{1}$ was significantly higher than $T_{2}(P \leq 0.01)$. The specific growth rate was $558 \%$ in $T_{1}$ and $480 \%$ in $T_{2}$. The specific growth rate in $T_{1}$ was significantly higher than $T_{2}(P \leq 0.01)$. The food conversion ratio was 5.28 in $T_{1}$ and 6.10 in $T_{2}$. The food conversion ratio ( $\left.F C R\right)$ in $T_{1}$ was significantly lower than $\mathrm{T}_{2}(\mathrm{P} \leq 0.01)$. The gross production was $2.40 \mathrm{ton} / \mathrm{ha} / \mathrm{yr}$ in $\mathrm{T}_{1}$ and $2.08 \mathrm{ton} / \mathrm{ha} / \mathrm{yr}$ in $\mathrm{T}_{2}$. The gross production in $\mathrm{T}_{1}$ was significantly higher than $\mathrm{T}_{2}(\mathrm{P} \leq 0.01)$. The net production was $2.26 \mathrm{ton} / \mathrm{ha} / \mathrm{yr}$ in $\mathrm{T}_{1}$ and 1.94 ton/ha/yrin $T_{2}$. The net production in $T_{1}$ was significantly higher than $T_{2}(P \leq 0.01)$.

Talukder et al. (2004) found SGR of fish ( $P$. gonionotus) from 2.42 to $2.03 \%$ in treatment-1 and treatment-2 respectively where duck weed were used as supplemental feed at a rate of $40 \%$ body weight.Talukder et al. (2004) found 2.76 ton/ha/yr net production of sharpunti where fresh duck weed was supplemental feed and the production was significantly higher in ponds with supply of duck weed than without supply of duck weed. Kohinoor et al. (1999) observed the effectiveness of duck weed as low cost supplementary feed through 6 months production trial of Thai sharpunti. Abdel-Fattah and Abdel-Aziz (1990) used Azolla pinnata as protein source for tilapia (Oreochromis niloticus) fingerlings. FCR value in $\mathrm{T}_{1}$ was significantly lower than $T_{2}$. The reason behind the higher production in $T_{1}$ was due to the supply of duck weed as dietary feed which had higher nutritive value of protein content then Azolla fern in $\mathrm{T}_{2}$.

$\mathrm{F}$-test of gross and net productions showed( $\mathrm{P} \leq 0.01,0.05)$ significantly higher production in $\mathrm{T}_{1}$ than $\mathrm{T}_{2}$ i.e. influence of duck weed as dietary feed on the production of Thai Sharpunti ( $P$. gonionotus) was positively significant. So it might be concluded that duckweed had better effect as dietary feed than Azolla fern on monoculture of Thai sharpunti.

Table 3. Proximate Composition of $100 \mathrm{~g}$ supplied Duckweed and Azolla fern

\begin{tabular}{lll}
\hline Compositon $(\mathrm{g})$ & Duckweed per $\mathbf{1 0 0 \mathrm { g }}$ & Azolla fern per $\mathbf{1 0 0 \mathrm { g }}$ \\
\hline Crude protein(g) & 38.86 & 25.78 \\
Crude fibre $(\mathrm{g})$ & 13.22 & 15.71 \\
Crude fat $(\mathrm{g})$ & 3.80 & 3.47 \\
Moisture $(\mathrm{g})$ & 3.00 & 9.2 \\
Ash $(\mathrm{g})$ & 16.00 & 15.76 \\
Dry matter $(\mathrm{g})$ & 97.00 & 90.8 \\
Gross energy (Kcal) & 325.7 (Kcal) & $262.05($ Kcal $)$ \\
\hline
\end{tabular}

Energy distribution mechanism in Thai Sharpunti(Puntius gonionotus)

- $\quad$ Sharpunti $(100 \mathrm{C})=20 \mathrm{P}+37 \mathrm{R}+2 \mathrm{U}+41 \mathrm{~F}$

- $\quad$ Duck weed $(2953.76)=410 P+1092 R+59 U+1210 F$

- Azolla fern $(1855.94)=371 P+686 R+37 U+760 F$

Where,

$C($ Consumtion $)=$ The gross energy content of the food ingested .

$\mathrm{P}($ Production $)=$ Energy utilized in growth materials .

$R($ Respiration $)=$ Net loss of energy as heat.

$U$ (Urinary loss) = Energy loss in nitrogenous excretory product.

$\mathrm{F}($ Fecal loss $)=$ Energy loss in the feces.

\section{CONCLUSION}

The present study showed higher growth performance in treatment-1 followed by treatment-2.The net fish production was 1.32 times higher than $\mathrm{T}_{2}$. FCR value in $\mathrm{T}_{1}$ was significantly lower than $\mathrm{T}_{2}$. F-test of gross and net productions showed $(P \leq 0.01,0.05)$ significantly higher production in $T_{1}$ than $T_{2}$ i.e. influence of duck weed as dietary feed on the production of Thai Sharpunti ( $P$. gonionotus) was positively significant. So it might be concluded that duckweed had better effect as dietary feed than Azolla fern on monoculture of Thai sharpunti.

\section{REFERENCES}


1. Abdel-Fattah and SH Abdel-Aziz, 1990. The use of Azollapinnata protein source for tilapia (Oreochromis niloticus L.) fingerlings. Proceeding of International a source of feed stuff in formulated diets for rohu (Labeorohita Ham.) fingerlings after fermentation with a fish intestinal bacterium. Bioresource Technology, 85: 17- 24.

2. Akhtaruzzaman, 1991. Silver bard respond well to comparatively low cost simple management practices. Durve, V. S. and D.V.Bal. 1961.

3. Aminul IM, 1996. Qualities of water and soil in Aquaculture, Fish week compilation, 96. DoF Publication, Ramna, Dhaka-1000.

4. Azim ME and MA Wahab, 2003. Development of a duckweed fed carp polyculture system in Bangladesh. Aquaculture, 218: 425-435.

5. Dewan S, MA Wahab, MCM Beveridge, MH Rahman and BK Sarker, 1991. Food selection, electivity and dietary overlap among planktivorous Chinese and Indian Major carp fry and fingerlings grown in extensively managed, rain-fed ponds in Bangladesh. Aquaculture and Fisheries Management, 22: 277-294.

6. Haque MS, 2005. Use of duckweed (Lemna minor) as supplementary feed in monoculture of Sharpunti (Puntius gononotus). M. S. Thesis, Department of Fisheries Management, Bangladesh Agricultural University, Mymensingh. 87 pp.

7. Israfil EH, 2000. L.R. Kabir 2003. Effects of chemical parameters on Eshakhalake in BAU campus. An M.S. thesis submitted to the Department of Fisheries Biology and Limnology, Bangladesh Agricultural University, Mymensingh, Bangladesh. 86 pp.

8. Israfil M, 2000. Effects of periphyton on monoculture of Thai Sharputi (Puntius gonionotus). M. S. Thesis, Department of Fisheries Management, Bangladesh Agricultural University, Mymensingh.

9. Kabir ANMA, 2003. Use of duckweed (Lemna minor) as feed for fishes in polyculture. M. S. Thesis, Department of Fisheries Management, Bangladesh Agricultural University, Mymensingh. 74 pp.

10. Kohinoor AHM, 2000. Development of culture technology of three small indigenous fish mola (Amblypharyngodon mola), punti (Puntius sophore) and chela (Chela cachius) with notes on some aspects of their biology. Ph.D. Thesis, Department of Fisheries Management, BAU, Mymensingh. $363 \mathrm{pp}$.

11. Kohinoor AHM, MS Islam, N Begum and MG Hussain, 1999. Production of Thai sharpunti (Barbodes gonionotus Bleeker) in poly culture with carps using low-cost feed. Bangladesh Journal of Fisheries Research, 3: 157-164.

12. Noor J, MA Hossain, MM Bari and KM Azimuddin, 2004. Effect of duckweed (Lemna minor) as dietary fish meal substitute for silver barb (Barbodes gonionotus Bleeker). Bangladesh Journal of Fisheries Research 4: 35-42.

13. Rahman MA and MG Hussain, 2000. Present status, potentials and contrain for developing fisheries resources in Bangladesh. Apaper presented in the seminer on Socioeconomic Aspect of developing Fisheries resources in Bangladesh held in BAU, Mymensingh, June 25-26.

14. Rahman MS, 1992, Water Quality Management in Aquaculture. Published by Bangladesh Rural Advancement Committee.pp.75.

15. Talukder LL, DT Gantt, DM Williams and JH Gholson, 2004. Effect of duckweed (Lemna minor) as dietary fish meal substitute for silver barb (Barbodes gonionotus Bleeker) Bangladesh Journal of Fisheries Research, 2: 35-42.

16. Wahab MA and MK Ganapati, 1995. Seasonal changes in the physico- chemical parameters of garden pond containing abundant aquatic vegetation Journal of Maghalaya University, 13: 5567.

17. Wahab MA, ZF Ahmed, MA Islam and SM Rahmatullah, 1995. Effect of introduction of carp, Cyprinuscarpio $(L)$ on the pond ecology and growth of fish in polyculture. Aquaculture Research, 26: 619-628. 